\title{
Comparison of Rehabilitation Programs After Arthroscopic Rotator Cuff Repair in Terms of Timing
}

\author{
Artroskopik Rotator Manşet Onarımı Sonrası Rehabilitasyon Programlarının Zamanlama Açısından \\ Karşılaştırılması
}

\author{
Kadir İlker YILDIZ ${ }^{1}$ \\ (i) 0000-0003-2034-9974 \\ Turan Bilge KIZKAPAN ${ }^{2}$ \\ (D) 0000-0002-6614-888X
}

\begin{abstract}
Aim: The aim of this study was to determine and compare the effects of early and delayed passive joint rehabilitation protocol on functional and quality of life outcomes in patients following arthroscopic rotator cuff repair (RCR).

Material and Methods: A total of 202 patients who underwent arthroscopic RCR were included into the study. Ninety eight patients who started the rehabilitation program just after the arthroscopic RCR were comprised as early rehabilitation (ER) group, while 104 patients whose shoulder joint motion was not allowed for 3 weeks after surgery as delayed rehabilitation (DR) group. Demographic characteristics, preoperative and postoperative American Shoulder and Elbow Surgeons (ASES) score, Constant Murley (CM) score, visual analogue scale (VAS), and the 36-item Short Form Health Survey (SF-36) scores were evaluated.

Results: There was no significant difference between the ER and the DR groups in terms of improvement of ASES, CM, VAS and SF-36 scores after arthroscopic RCR. There was no difference between two groups in terms of complications such as re-tear, frozen shoulder and infection that developed during the follow-up period. Both rehabilitation protocols were found to have a similar effect on patient-reported outcomes.

Conclusion: At a mean follow-up time of 13 months, early and delayed onset postoperative rehabilitation programs are associated with similar functional and quality of life outcomes, and complication rates. Therefore, DR can be preferred primarily in patients with large tears. ER can be an option for the patients with small tears who has anticipation of early return to work and daily life.
\end{abstract}

Keywords: Shoulder; arthroscopy; rotator cuff injuries; rehabilitation.

\section{ÖZ}

Amaç: Bu çalışmanın amacı, artroskopik rotator manşet onarımını (RMO) takiben hastalarda erken ve ertelemeli pasif eklem rehabilitasyon protokolünün fonksiyonel sonuçlar ve yaşam kalitesi üzerindeki etkilerini belirlemek ve karşılaştırmaktır.

Gereç ve Yöntemler: Çalışmaya artroskopik RMO uygulanan toplam 202 hasta dahil edildi. Artroskopik RMO'dan hemen sonra rehabilitasyon programına başlayan 98 hasta erken rehabilitasyon (early rehabilitation, ER), ameliyat sonrasi 3 hafta omuz eklem hareketine izin verilmeyen 104 hasta ise gecikmiş rehabilitasyon (delayed rehabilitation, DR) grubunu oluşturmaktaydı. Demografik özellikler, ameliyat öncesi ve ameliyat sonrası Amerikan Omuz ve Dirsek Cerrahları (American Shoulder and Elbow Surgeons, ASES) skoru, Sabit Murley (Constant Murley, CM) skoru, görsel analog skala (visual analogue scale, VAS) ve 36 maddelik Kısa Form Sağlık Anketi (SF-36) skorları değerlendirildi.

Bulgular: Artroskopik RMO sonrası ASES, CM, VAS ve SF-36 skorlarının iyileşmesinde ER ve DR grupları arasında anlamlı bir fark saptanmadı. İki grup arasında takip süresince gelişen tekrar yırtık nüksü, donuk omuz ve enfeksiyon gibi komplikasyonlar açısından fark yoktu. Her iki rehabilitasyon protokolünün de hasta tarafindan bildirilen sonuçlar üzerinde benzer bir etkiye sahip olduğu görüldü.

Sonuç: Ortalama 13 aylık bir takip süresinde, erken ve gecikmiş başlangıçlı postoperatif rehabilitasyon programları, benzer fonksiyonel ve yaşam kalitesi sonuçları ve komplikasyon oranları ile ilişkilidir. Bu nedenle DR, özellikle büyük yırtıklara sahip hastalarda öncelikli olarak tercih edilebilir. ER, işe ve günlük hayata erken dönüş beklentisi olan küçük yırtıklara sahip hastalar için bir seçenek olabilir.

Received / Geliş Tarihi : 15.02. Accepted / Kabul Tarihi : 17.04.2021 Available Online /

Çevrimiçi Yayın Tarihi : 22.04.2021

\section{sahip hastalar için bir seçenek olabilir.}




\section{INTRODUCTION}

In the treatment of patients undergoing rotator cuff repair (RCR), physical therapy is generally an important component (1). The purpose of rehabilitation after RCR is to prevent re-rupture, reduce pain, increase range of motion (ROM) and return to normal functional activities as soon as possible (2). The effects of rehabilitation techniques on postoperative recovery have been increasingly considered $(3,4)$. It has been stated that the timing of rehabilitation programs is important for early joint movement acquisition and strengthening (5). There is a consensus that early onset of passive ROM reduces the risk of joint stiffness and provides earlier functional activity gain (6). However, it has been emphasized that this rehabilitation can put excessive stress on the repair area and increase the risk of anatomical failure (7). Due to concerns about tendon healing, delayed rehabilitation protocol with early immobilization has started to gain popularity (8). It is thought that delayed rehabilitation protocols can prevent situations that may adversely affect tendon healing such as micro-motion and cavity formation in the repair area. However, delayed joint motion may increase the risk of joint stiffness after surgery and potentially delay the return of shoulder function (9). Because of these conflicting findings, there is no definitive consensus on the initiation of a rehabilitation after RCR (3). The aim of this study is to determine and compare the effects of early-onset passive joint rehabilitation and lateonset rehabilitation after immobilization on quality of life and clinical outcomes after arthroscopic RCR.

\section{MATERIAL AND METHODS}

Following the approval of Uludağ University Clinical Research Ethics Committee (08.07.2020, 12/12), archive records were retrospectively reviewed, and 237 patients who underwent arthroscopic RCR due to full-thickness isolated supraspinatus rupture between January 2017 and January 2020 were identified. Early rehabilitation (ER) was applied to 125 of the patients and delayed rehabilitation (DR) was applied to 112 of them. Twenty four patients with an $\mathrm{L}$ or inverted $\mathrm{L}$-shaped tear pattern, associated labral pathology, glenohumeral arthritis, cervical spine pathologies, or degenerative joint diseases were excluded. Of the remaining 213 patients, 11 were excluded due to follow-up incompatibility. Subsequently, 202 patients aged between 18-70 years, with full thickness isolated supraspinatus tendon rupture on magnetic resonance imaging (MRI) and confirmed arthroscopically by isolated full-thickness crescent-shaped supraspinatus rupture of the rotator cuff were included (Figure 1). Postoperative Rehabilitation Protocols

All operations were performed using the same surgical technique and patients were referred to two different rehabilitation protocols.

Early rehabilitation (ER): After the arthroscopic RCR, they immediately started the rehabilitation program. On the postoperative $1^{\text {st }}$ day, passive shoulder exercises were initiated as much as the patients could tolerate. Pendulum exercises were initiated at the first week. Passive shoulder joint exercises have been continued under the supervision of a physiotherapist until the $6^{\text {th }}$ week. The patients were advised to continue their exercises at home in sets of 10,5 times a day. Active shoulder motions were allowed at the end of the $6^{\text {th }}$ week and strengthening exercises were started at the $3^{\text {rd }}$ month. When not exercising, a shoulder arm sling was used in the neutral position for the first 6 weeks.

Delayed Rehabilitation (DR): Shoulder joint motion was not allowed for 3 weeks after arthroscopic RCR, but elbow and wrist joint movements were allowed. After 3 weeks, passive shoulder exercises were initiated for the patients to the extent that they could tolerate, and pendulum exercises were started. The patients were advised to continue their exercises at home in sets of 10,5 times a day. Active shoulder motions were allowed after the $6^{\text {th }}$ week and strengthening exercises were started at the $3^{\text {rd }}$ month. A shoulder arm sling was used for all patients in the neutral position for the first 6 weeks.

\section{Evaluation of Demographic and Clinical Findings}

In both groups, age, gender, operated side, status of dominance in surgical side, duration of shoulder symptoms, follow-up period, tear size, working status, tear chronicity ( $<3$ months acute, $>3$ months chronic) and complications (frozen shoulder, re-tear, infection) were compared. Rotator cuff rupture was classified by using MRI. According to DeOrio and Cofield classification; tears of $1 \mathrm{~cm}$ and less were classified as small, $1-3 \mathrm{~cm}$ medium, $3-5 \mathrm{~cm}$ large tears, and massive tears greater than $5 \mathrm{~cm}$ (10). The results of the American Shoulder and Elbow Surgeons (ASES) score, constant Murley (CM) score, visual analogue scale (VAS), and the 36-item Short Form Health Survey (SF-36) questionnaire recorded by an independent observer were used in clinical evaluation.

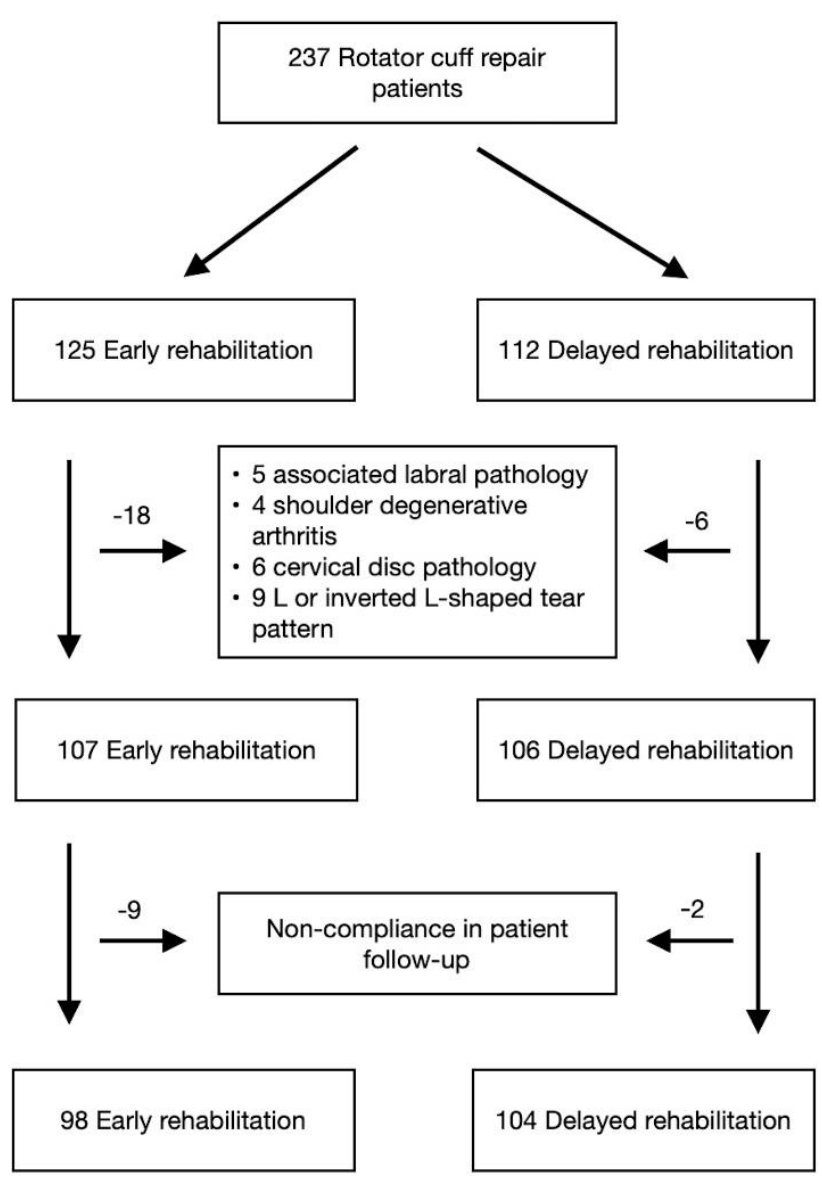

Figure 1. Flowchart of the study design, exclusion steps and the numbers of excluded patients 


\section{Surgical Technique}

All patients were operated by two experienced surgeons under general anesthesia in beach chair position. Diagnostic arthroscopy was initially performed to assess the size of the rotator cuff tear, any lesions in the biceps tendon, and other associated lesions. Radiofrequency cauterization and adrenaline-supplemented irrigation fluid were used for bleeding control, and systolic blood pressure was controlled by anesthesiology. The fluid pressure was kept at an average of $40 \mathrm{mmHg}$ with the arthroscopic pump. Rotator cuff repair was performed by using a Smith\&Nephew (London, UK) TWINFIX ${ }^{\circledR}$ suture anchor with an ULTRABRAID® suture or a FOOTPRINT PK ${ }^{\circledR}$ suture anchor. Following RCR, the anterior aspect of the coracoacromial ligament was released in 76 patients, and subacromial decompression was performed in 113 patients. Statistical Analysis

The mean, standard deviation, frequency and percentage values were used in the descriptive statistics. KolmogorovSmirnov test was used to evaluate distribution of the data. Independent samples $\mathrm{t}$ test was used to compare quantitative data, and Pearson chi-square or Fisher's exact test was used to compare qualitative data between groups. Pre till postoperative changes were evaluated by using two-way repeated measures analysis of variance. All statistical analyzes were performed by using SPSS v.24 (SPSS Inc., Armonk, NY) statistical package, and p values $<0.05$ were considered as statistically significant.

\section{RESULTS}

There were 98 ( 52 female/46 male) patients in the ER group and 104 (58 female/46 male) patients in the DR group. Follow-up time was $14.85 \pm 4.88$ months in ER group, and $13.14 \pm 4.25$ months in DR group $(\mathrm{p}=0.006)$. The duration of the symptoms for the patients in ER group was $6.44 \pm 2.51$ months and $84(85.7 \%)$ patients had chronic tears. In $60(61.2 \%)$ patients, the tear was on the dominant side. The mean duration of symptoms in DR group was $5.86 \pm 2.31$ months. $85(81.7 \%)$ patients' tears in this group were chronic and $57(54.8 \%)$ of them were on the dominant side. No significant difference was found in both groups in terms of age, gender distributions, working status, surgical side, status of dominance in surgical side, duration of symptoms, tear chronicity or tear size (Table 1).

Mean preoperative ASES, CM and VAS values were $41.76 \pm 7.26,41.36 \pm 5.91$ and $6.33 \pm 0.89$ in ER group, respectively, while they were $43.09 \pm 7.02,41.72 \pm 5.13$ and $6.06 \pm 0.78$ in DR group. Mean postoperative ASES, CM and VAS values were 77.62 $\pm 11.77,76.92 \pm 11.82$ and $2.03 \pm 1.46$ in ER group, respectively, while they were $77.63 \pm 12.22,77.48 \pm 11.64$ and $1.99 \pm 1.31$ in DR group. There were statistically significant improvements in ASES, CM, VAS, SF-36 scores in both groups. However, there was no significant difference between two groups in terms of preoperative and postoperative clinical scores (Table 2).

$\underline{\text { Table 1. Demographics and disease-specific characteristics }}$

\begin{tabular}{|c|c|c|c|}
\hline & $\begin{array}{c}\text { ER Group } \\
(\mathbf{n}=98)\end{array}$ & $\begin{array}{c}\text { DR Group } \\
(n=104)\end{array}$ & $\mathbf{p}$ \\
\hline Age (years), mean \pm SD & $62.72 \pm 6.36$ & $62.88 \pm 6.38$ & 0.859 \\
\hline \multicolumn{4}{|l|}{ Gender, n (\%) } \\
\hline Female & $52(53.1)$ & $58(55.8)$ & \multirow{2}{*}{0.699} \\
\hline Male & $46(46.9)$ & $46(44.2)$ & \\
\hline \multicolumn{4}{|l|}{ Working status, n (\%) } \\
\hline No/Housewife & $20(20.4)$ & $19(18.3)$ & \multirow{4}{*}{0.844} \\
\hline Officer & $25(25.5)$ & $22(21.2)$ & \\
\hline Worker & $22(22.4)$ & $28(26.9)$ & \\
\hline Retired & $31(31.6)$ & $35(33.7)$ & \\
\hline \multicolumn{4}{|l|}{ Injured side, n (\%) } \\
\hline Right & $53(54.1)$ & $48(46.2)$ & \multirow{2}{*}{0.260} \\
\hline Left & $45(45.9)$ & $56(53.8)$ & \\
\hline \multicolumn{4}{|l|}{ Injured side, n (\%) } \\
\hline Dominant & $60(61.2)$ & $57(54.8)$ & \multirow{2}{*}{0.356} \\
\hline Non-dominant & $38(38.8)$ & $47(45.2)$ & \\
\hline \multicolumn{4}{|l|}{ Tear chronicity, n (\%) } \\
\hline Acute & $14(14.3)$ & $19(18.3)$ & \multirow{2}{*}{0.444} \\
\hline Chronic & $84(85.7)$ & $85(81.7)$ & \\
\hline \multicolumn{4}{|l|}{ Tear size, n (\%) } \\
\hline Small & $24(24.5)$ & $30(28.8)$ & \multirow{3}{*}{0.770} \\
\hline Medium & $54(55.1)$ & $53(51)$ & \\
\hline Large & $20(20.4)$ & $21(20.2)$ & \\
\hline $\begin{array}{l}\text { Duration of symptoms } \\
\text { (months), mean } \pm \text { SD }\end{array}$ & $6.44 \pm 2.51$ & $5.86 \pm 2.31$ & 0.087 \\
\hline $\begin{array}{l}\text { Follow-up time } \\
\text { (months), mean } \pm \text { SD }\end{array}$ & $14.85 \pm 4.88$ & $13.14 \pm 4.25$ & 0.006 \\
\hline
\end{tabular}

ER: early rehabilitation, DR: delayed rehabilitation, SD: standard deviation

Table 2. Comparison of the clinical scores within and between the groups

\begin{tabular}{lcccccc}
\hline & \multicolumn{2}{c}{ ER Group (n=98) } & \multicolumn{2}{c}{ DR Group (n=104) } & \multirow{2}{*}{$\mathbf{p}_{\mathbf{w}}$} & $\mathbf{p}_{\mathbf{B}}$ \\
\cline { 2 - 5 } & Preoperative & Postoperative & Preoperative & Postoperative & & \\
\hline ASES score & $41.76 \pm 7.26$ & $77.62 \pm 11.77$ & $43.09 \pm 7.02$ & $77.63 \pm 12.22$ & $<\mathbf{0 . 0 0 1}$ & 0.611 \\
CM score & $41.36 \pm 5.91$ & $76.92 \pm 11.82$ & $41.72 \pm 5.13$ & $77.48 \pm 11.64$ & $<\mathbf{0 . 0 0 1}$ & 0.644 \\
VAS & $6.33 \pm 0.89$ & $2.03 \pm 1.46$ & $6.06 \pm 0.78$ & $1.99 \pm 1.31$ & $<\mathbf{0 . 0 0 1}$ & 0.246 \\
SF-36 & & & & & \\
Physical functioning & $58.92 \pm 8.13$ & $83.87 \pm 11.54$ & $60.19 \pm 9.00$ & $85.62 \pm 9.96$ & $<\mathbf{0 . 0 0 1}$ & 0.584 \\
Role limitations due to physical health & $16.58 \pm 15.20$ & $73.72 \pm 15.80$ & $21.44 \pm 18.32$ & $76.44 \pm 15.11$ & $<\mathbf{0 . 0 0 1}$ & 0.496 \\
Role limitations due to emotional problems & $40.15 \pm 27.09$ & $86.86 \pm 19.18$ & $39.08 \pm 25.62$ & $86.95 \pm 17.85$ & $<\mathbf{0 . 0 0 1}$ & 0.747 \\
Energy/fatigue & $29.94 \pm 10.7$ & $75.00 \pm 13.86$ & $30.67 \pm 11.27$ & $75.52 \pm 14.26$ & $<\mathbf{0 . 0 0 1}$ & 0.766 \\
Emotional well-being & $32.73 \pm 12.21$ & $66.36 \pm 17.38$ & $34.69 \pm 11.41$ & $68.73 \pm 17.14$ & $<\mathbf{0 . 0 0 1}$ & 0.547 \\
Social functioning & $27.99 \pm 9.63$ & $72.96 \pm 13.37$ & $28.81 \pm 10.82$ & $73.55 \pm 12.95$ & $<\mathbf{0 . 0 0 1}$ & 0.909 \\
Pain & $22.75 \pm 9.98$ & $73.96 \pm 21.50$ & $23.85 \pm 9.72$ & $75.68 \pm 19.40$ & $<\mathbf{0 . 0 0 1}$ & 0.502 \\
General health & $28.46 \pm 12.56$ & $75.66 \pm 15.60$ & $28.99 \pm 13.71$ & $76.34 \pm 15.90$ & $<\mathbf{0 . 0 0 1}$ & 0.623 \\
Health change & $19.13 \pm 15.14$ & $80.36 \pm 18.73$ & $20.67 \pm 17.57$ & $81.25 \pm 17.33$ & $<\mathbf{0 . 0 0 1}$ & 0.838 \\
\hline
\end{tabular}




\section{Complications}

Superficial infection occurred in $5(2.4 \%)$ of all patients. Of these, 2 (2.04\%) were in ER group and 3 (2.94\%) were in DR group $(\mathrm{p}=0.999)$. All patients recovered with systemic antibiotics and surgical debridement was not required for any of them. Frozen shoulder occurred in 16 patients $(7.9 \%)$ postoperatively; $6(6.1 \%)$ of them were in ER group and $10(9.6 \%)$ of them were in DR group $(\mathrm{p}=0.358)$. Re-tears occurred in $13(6.4 \%)$ patients; 8 $(8.2 \%)$ of them were observed in ER group and 5 (4.8\%) of them were in DR group $(\mathrm{p}=0.331)$. The rate of re-tear increased as the initial size of the tear increased. While no re-tear was observed in the small tear group, it was observed in $2(1.9 \%)$ of medium tear and $11(26.8 \%)$ of large tear groups (Table 3 ).

\section{DISCUSSION}

The most important finding obtained in this study is that no significant clinical and functional difference was found between ER and DR in mid-term follow-up after RCR.

Currently, arthroscopic repair is widely used in the treatment of the rotator cuff tears. Physical rehabilitation after repair has a very important role in the recovery of patients (1). However, the timing of postoperative rehabilitation in these patients is still a matter of debate $(8,11)$. In many studies, any important advantage or disadvantage of early or late-onset rehabilitation after arthroscopic RCR compared to each other could not be revealed (12-15). However, there are studies that prefers the ER protocol because it provides better range of motion, causes less shoulder stiffness and muscle atrophy, increases patient satisfaction and facilitates return to daily life $(16,17)$. It was stated that patients who received a supervised early exercise program after RCR would benefit more in terms of shoulder function, pain reduction and range of motion compared to those who received a standard exercise program (18). In a review, it was reported that good clinical and functional results and range of motion were obtained in the early postoperative period with ER protocols, by the way similar results were achieved between 3-6 months with DR protocols (19). On the other hand, Longo et al. (20) achieved better clinical and functional results in patients with limited rehabilitation compared to patients who received early aggressive rehabilitation. Also Koh et al. (12) demonstrated that DR provides similar clinical outcomes without an increase in postoperative structural failure. The DR protocol after RCR is preferred due to the concern that early movement may adversely affect tendon healing from micro-movement and cavity formation in the repair area. However, delayed motion can increase the risk of joint stiffness after surgery and potentially delay the return of shoulder function (9). Some studies have indicated that the ER protocol after arthroscopic RCR increases the risk of re-tear, especially in patients with large tears between $3 \mathrm{~cm}$ and $5 \mathrm{~cm}(21,22)$. On the contrary, some authors found that there was no difference in terms of re-tear between ER and DR applied in patients with small and moderate size tears $(5,23,24)$. In the review of Bakti et al. $(25)$, it was stated that DR after RCR will reduce the risk of re-tear and provide improvement in subjective outcome measures. It has been emphasized that the stiffness that may be encountered in DR is insignificant compared to the clinical
Table 3. Comparison of complications between the groups

\begin{tabular}{lccc}
\hline & $\begin{array}{c}\text { ER Group } \\
(\mathbf{n = 9 8})\end{array}$ & $\begin{array}{c}\text { DR Group } \\
(\mathbf{n = 1 0 4 )}\end{array}$ & $\mathbf{p}$ \\
\hline Superficial infection & $2(2.04)$ & $3(2.94)$ & 0.999 \\
Frozen shoulder, n (\%) & $6(6.1)$ & $10(9.6)$ & 0.358 \\
Re-rupture, n (\%) & $8(8.2)$ & $5(4.8)$ & 0.331 \\
Tear size, n (\%) & & & \\
$\quad$ Small (n=54) & $0(0.0)$ & $0(0.0)$ & \\
$\quad$ Medium (n=107) & $1(0.9)$ & $1(0.9)$ & \\
$\quad$ Large (n=41) & $7(17.1)$ & $4(9.8)$ & \\
\hline ER: early rehabilitation, DR: delayed rehabilitation & &
\end{tabular}

difficulties in re-tear. Unrelated to physical therapy after surgery, shoulder activity in the first 2 years after surgery was also associated with a higher risk of re-tear in patients who underwent RCR (26). Beneficial effects of a period of immobilization on the structural quality and strength of the healing tissue have been provided by animal model studies and that it is not detrimental to $\operatorname{ROM}(27,28)$. Kovacevic et al. (29) found that by reducing the load, the quality of tendon-bone healing increased. It was reported that immobilization plays a role in allowing healing and the natural phases of inflammation and proliferation (30). However, the healing process differs between animal models and human subjects. While the rotator cuff muscles of humans do not contract during passive ROM, these muscles contract unless the animals are under anesthesia. The rehabilitation initiation time after rotator cuff surgery is an important point in determining which benefits and side effects may occur. These contradictory findings lead to a lack of definitive conclusions as to whether early-onset rehabilitation protocols are harmful or beneficial after RCR (3).

In present study, mean follow-up time was 13.97 months. The rate of re-tear during this period was $6.4 \%$. This rate was significantly lower than the $20 \%$ to $90 \%$ re-rupture rate reported in previous studies (31). The data obtained in this study showed that re-tears may occur in both rehabilitation protocols in patients with large tears. Due to the absence of MRI or any other radiological evaluation after arthroscopic repair, the actual incidence of re-tear may be higher than detected. Asymptomatic partial retears might have been missed. With postoperative control MRI and longer follow-up time, higher rates of re-tear may be detected. Also, there was no difference between the groups in terms of other postoperative complications such as superficial infection and frozen shoulder. Most studies showed comparable outcome scores, quite a few studies used a validated quality-of-life score. Mazzocca et al. (32) reported that there was a clinically significant difference between the early and late movement groups in their study using the WORC score. We used SF-36 for this purpose. There was no significant difference between ER and DR groups in terms of the preoperative ASES, CM, VAS and in all sub-scales of the SF-36 questionnaire. Similarly, there was no significant difference between the two groups in postoperative ASES, BM, VAS and all subscales of the SF-36 questionnaire. The improvements in all clinical scores in both groups were similar, suggesting that both rehabilitation protocols had similar effects on patientreported outcomes. Risk stratification can be applied to decide the best rehabilitation option for a particular patient. 
Given that DR does not pose an additional risk for joint stiffness and has a lower potential for structural deterioration, it may be preferable for large, full-thickness tears for a more successful outcome. On the other hand, ER may be an option in a selected patient population with small tears with anticipation of early return to work and early return to daily life.

To eliminate the risk of bias in the study, the presence of tears were confirmed on MRI images of each patient participating in the study by an independent blinded researcher. The adequacy of the repairs was confirmed by surgical video recordings. Then, clinical and functional scores of all patients were made by a blinded investigator. We think that this study model and the number of patients included in the study increase the power of the study.

The limitations of this study are that the patients did not have pre- and postoperative range of motion measurements and had a relatively short follow-up period. Apart from this, postoperative MRI scanning was not performed to determine subclinical RCR failure. Longer follow-up, detailed post-rehabilitation ROM measurements, and detailed radiological examinations could reveal more information about the benefits and side effects of each protocol.

\section{CONCLUSION}

At a mean follow-up of 13 months, early and delayed onset postoperative rehabilitation programs are associated with similar functional and quality of life outcomes and complication rates. Therefore, delayed rehabilitation can be preferred primarily in patients with large tears. Early rehabilitation can be selected for a limited patient population with small tears with anticipation of early return to work and daily life.

Ethics Committee Approval: The study was approved by the Ethics Committee of Uludağ University Faculty of Medicine (08.07.2020, 12/12).

Conflict of Interest: None declared by the authors.

Financial Disclosure: None declared by the authors.

Acknowledgements: None declared by the authors.

Author Contributions: Idea/Concept: KIY, TBK; Design: KIY, TBK; Data Collection/Processing: KIY, TBK; Analysis/Interpretation: KIY; Literature Review: KIY; Drafting/Writing: KIY; Critical Review: KIY, TBK.

\section{REFERENCES}

1. Cuff DJ, Pupello DR. Prospective randomized study of arthroscopic rotator cuff repair using an early versus delayed postoperative physical therapy protocol. J Shoulder Elbow Surg. 2012;21(11):1450-5.

2. Ross D, Maerz T, Lynch J, Norris S, Baker K, Anderson K. Rehabilitation following ar-throscopic rotator cuff repair: a review of current literature. J Am Acad Orthop Surg. 2014;22(1):1-9.

3. Keener JD, Galatz LM, Stobbs-Cucchi G, Patton R, Yamaguchi K. Rehabilitation following arthroscopic rotator cuff repair: a prospective randomized trial of immobilization com-pared with early motion. J Bone Joint Surg Am. 2014;96(1):11-9.

4. Kim YS, Chung SW, Kim JY, Ok JH, Park I, Oh JH. Is early passive motion exercise necessary after arthroscopic rotator cuff repair? Am J Sports Med. 2012;40(4):815-21.

5. Riboh JC, Garrigues GE. Early passive motion versus immobilization after arthroscopic rotator cuff repair. Arthroscopy. 2014;30(8):997-1005.

6. Thigpen CA, Shaffer MA, Gaunt BW, Leggin BG, Williams GR, Wilcox RB 3rd. The American Society of Shoulder and Elbow Therapists' consensus statement on rehabilitation following arthroscopic rotator cuff repair. J Shoulder Elbow Surg. 2016;25(4):521-35.

7. Thomopoulos S, Williams GR, Soslowsky LJ. Tendon to bone healing: differences in biomechanical, structural, and compositional properties due to a range of activity levels. J Biomech Eng. 2003;125(1):106-13.

8. Li S, Sun H, Luo X, Wang K, Wu G, Zhou J, et al. The clinical effect of rehabilitation following arthroscopic rotator cuff repair: A meta-analysis of early versus delayed passive motion. Medicine (Baltimore). 2018;97(2):e9625.

9. Cofield RH, Parvizi J, Hoffmeyer PJ, Lanzer WL, Ilstrup DM, Rowland CM. Surgical repair of chronic rotator cuff tears. A prospective long-term study. J Bone Joint Surg Am. 2001;83(1):71-7.

10. DeOrio JK, Cofield RH. Results of a second attempt at surgical repair of a failed initial rotator-cuff repair. J Bone Joint Surg Am. 1984;66(4):563-7.

11. Düzgün İ, Baltacı G, Atay OA. Comparison of slow and accelerated rehabilitation protocol after arthroscopic rotator cuff repair: pain and functional activity. Acta Orthop Traumatol Turc. 2011;45(1):23-33.

12. Koh KH, Lim TK, Shon MS, Park YE, Lee SW, Yoo JC. Effect of immobilization without passive exercise after rotator cuff repair: randomized clinical trial comparing four and eight weeks of immobilization. J Bone Joint Surg Am. 2014;96(6):e44.

13. Düzgün İ, Baltacı G, Turgut E, Atay OA. Effects of slow and accelerated rehabilita-tion protocols on range of motion after arthroscopic rotator cuff repair. Acta Orthop Traumatol Turc. 2014;48(6):642-8.

14. Kjær BH, Magnusson SP, Henriksen M, Warming S, Boyle E, Krogsgaard MR, et al. Effects of 12 weeks of progressive early active exercise therapy after surgical rotator cuff repair: 12 weeks and 1-year results from the CUT-N-MOVE randomized controlled trial. Am J Sports Med. 2021;49(2):321-31.

15. Sheps DM, Silveira A, Beaupre L, Styles-Tripp F, Balyk R, Lalani A, et al. Early active motion versus sling immobilization after arthroscopic rotator cuff repair: A randomized controlled trial. Arthroscopy. 2019;35(3):749-60.

16. Lastayo PC, Wright T, Jaffe R, Hartzel J. Continuous passive motion after repair of the rotator cuff. A prospective outcome study. J Bone Joint Surg Am. 1998;80(7):1002-11.

17. Choi S, Seo KB, Shim S, Shin JY, Kang H. Early and delayed postoperative rehabilitation after arthroscopic rotator cuff repair: A comparative study of clinical outcomes. Clin Shoulder Elb. 2019;22(4):190-4. 
18. Gutiérrez-Espinoza H, Araya-Quintanilla F, PintoConcha S, Zavala-González J, Gana-Hervias G, Cavero-Redondo I, et al. Effectiveness of supervised early exercise program in patients with arthroscopic rotator cuff repair: Study protocol clinical trial. Medicine (Baltimore). 2020;99(4):e18846.

19. Gallagher BP, Bishop ME, Tjoumakaris FP, Freedman KB. Early versus delayed rehabilitation following arthroscopic rotator cuff repair: A systematic review. Phys Sportsmed. 2015;43(2):178-87.

20. Longo UG, Rizzello G, Petrillo S, Loppini M, Maffulli $\mathrm{N}$, Denaro V. Conservative rehabilitation provides superior clinical results compared to early aggressive rehabilitation for rotator cuff repair: A retrospective comparative study. Medicina (Kaunas). 2019;55(8):402.

21. Kluczynski MA, Nayyar S, Marzo JM, Bisson LJ. Early versus delayed passive range of motion after rotator cuff repair: A systematic review and metaanalysis. Am J Sports Med. 2015;43(8):2057-63.

22. Chen L, Peng K, Zhang D, Peng J, Xing F, Xiang Z. Rehabilitation protocol after arthroscopic rotator cuff repair: early versus delayed motion. Int $\mathbf{J}$ Clin Exp Med. 2015;8(6):8329-38.

23. Chan K, MacDermid JC, Hoppe DJ, Ayeni OR, Bhandari M, Foote CJ, et al. Delayed versus early motion after arthroscopic rotator cuff repair: a metaanalysis. J Shoulder Elbow Surg. 2014;23(11):1631-9.

24. Shen C, Tang ZH, Hu JZ, Zou GY, Xiao RC, Yan DX. Does immobilization after arthroscopic rotator cuff repair increase tendon healing? A systematic review and meta-analysis. Arch Orthop Trauma Surg. 2014;134(9):1279-85.
25. Bakti N, Antonios T, Phadke A, Singh B. Early versus delayed mobilization following rotator cuff repair. J Clin Orthop Trauma. 2019;10(2):257-60.

26. Chen Y, Jiang F, Li H, Chen S, Qiao Y, Li Y, et al. Retears and concomitant functional impairments after rotator cuff repair: Shoulder activity as a risk factor. Am J Sports Med. 2020;48(4):931-8.

27. Peltz CD, Dourte LM, Kuntz AF, Sarver JJ, Kim SY, Williams GR, et al. The effect of postoperative passive motion on rotator cuff healing in a rat model. J Bone Joint Surg Am. 2009;91(10):2421-9.

28. Sarver JJ, Peltz CD, Dourte L, Reddy S, Williams GR, Soslowsky LJ. After rotator cuff repair, stiffness--but not the loss in range of motion--increased transiently for immobilized shoulders in a rat model. J Shoulder Elbow Surg. 2008;17(1 Suppl):108-13.

29. Kovacevic D, Rodeo SA. Biological augmentation of rotator cuff tendon repair. Clin Orthop Relat Res. 2008;466(3):622-33.

30. Henriksson M, Rockborn P, Good L. Range of motion training in brace vs. plaster immobilization after anterior cruciate ligament reconstruction: a prospective randomized comparison with a 2-year follow-up. Scand J Med Sci Sports. 2002;12(2):73-80.

31. Tashjian RZ, Hollins AM, Kim HM, Teefey SA, Middleton WD, Steger-May K, et al. Factors affecting healing rates after arthroscopic double-row rotator cuff repair. Am J Sports Med. 2010;38(12):2435-42.

32. Mazzocca AD, Arciero RA, Shea KP, Apostolakos JM, Solovyova O, Gomlinski G, et al. The effect of early range of motion on quality of life, clinical outcome, and repair integrity after arthroscopic rotator cuff repair. Arthroscopy. 2017;33(6):1138-48. 